\title{
Feeding Pattern of Under-Five Children during COVID-19 Pandemic
}

\author{
Mursid Tri Susilo ${ }^{1}$, Arif Rahmat Kurnia ${ }^{2}$, Fitriyatun Na'imah ${ }^{3}$, Muhammad Fadlil \\ Fatihunnajah $^{4}$, Annisa Wahyu Hidayah ${ }^{5}$ \\ \{mursid_ts@yahoo.co.id ${ }^{1}$, arifrahmatk@gmail.com ${ }^{2}$, fitriyatunnaimah@gmail.com ${ }^{3}$ \}
}

Universitas Negeri Semarang, Semarang, Indonesia ${ }^{1,2,3,4,5}$

\begin{abstract}
The world was shocked by Covid-19 (Coronavirus Diseases-19) pandemic at the end of 2019. The virus attacked the average person aged 49 years, while few cases were found in under-five children. Despite the fact that under-five can still be infected by Covid-19. It was very important for underfive to get foods rich of nutrients to boost immune system in preventing Covid19 infection. The pandemic threatens normal life, forcing parents and caregivers to adapt in term of feeding pattern. This study aims to obtain a clearer description related to feeding pattern in under-five children before and during Covid19 pandemic. A cross-sectional design was used in this study. Online questionnaires were distributed among mothers or caregivers of under-five children across provinces in Indonesia. Statistical data were analyzed by Mc Nemar test. There were no significant differences between feeding pattern before and during the Covid-19 pandemic ( $\mathrm{p}>0.05)$.
\end{abstract}

Keywords: Covid-19, feeding pattern, nutrition, under-five children

\section{Introduction}

An unexpected pandemic appeared in late of 2019 in Wuhan City, Hubei Province, China. The virus caused pneumonia-like symptoms along with unclear etiology [1], the case spread rapidly and was identified as a new type of coronavirus [2]. World Health Organization (WHO) confirmed a new name of this new strain of virus as Coronavirus Disease-19 (Covid-19). Several symptoms occured such fever, cough, myalgia or fatigue [3].

The virus attacked persons average of 49 years old with age range 16 to 76 years old [3], while fewer cases were found in children [4]. Even so, the prevalence of Covid-19 infections in children might be able to increase in the future, a small number at the outset did not mean they were not susceptible to infection. In fact, children especially under-five could still be infected by Covid-19 [4]. Preliminary evidence suggests children were just as likely as adults to become infected with Covid-19 but were less likely to be symptomatic or develop severe symptoms. However, the importance of children in transmitting the virus remains unclear. Children more often had gastrointestinal symptoms compared to adults [5] 
It was very important for under-five children to get foods rich of nutrients to boost their immune system, capture growth and development. The pandemic caused by Covid-19 threatens normal life therefore parents or caregivers might not be able to leave the house just to get groceries or ready-to-eat foods normally for their children. This phenomenon forced parents and caregivers to adapt in feeding their children. They might order online food more often than go to grocery store or market for shopping. The Covid-19 pandemic has led to a sharp increase in online trade [6]. Accordingly, it was necessary to identify parent adaptation regarding children feeding pattern in term of fullfilling nutritional requirement during Covid-19 pandemic. Such information would be valuable so that appropriate recommendations could be taken to support nutritional achievement of the children.

\section{Materials and Methods}

Design of the study was cross-sectional. It used consecutive sampling to recruit respondents, they were mothers or care givers who take care of under-five children among several islands in Indonesia. Sample size was determined by slovin formula. Online questionnaires were distributed among respondent contains of subject characteristics informations, food pattern before and during Covid-19 pandemic. Data were analyzed by Statistical Package for the Social Sciences (SPSS) software using Mc-Nemar test.

\section{$3 \quad$ Results and Discussions}

\subsection{Subject Characteristics}

There were 83 respondents participated in this study, 78 respondents filled out the online questionnaire completely while 5 of them were inclomplete. . Subject characteristics were described in Table 1. Subjects were collected from Java, Sumatra, Kalimantan and Sulawesi islands. The average family income before Covid-19 pandemic was 3.000.000 - 3.999.999 IDR meanwhile declined to 2.000.000 2.999.999 IDR during pandemic.

Most of father had undergraduate or higher education 48 subjects $(61.5 \%)$, it showed that they were well educated. This fact also occured in mothers who are equally well educated. It was common for fathers to work in private sectors. However, there was an issue to be unemployed especially private employee who changed to be unemployed or farmer or trader. It was indicated by an increase in the number of unemployed father who initially all of them worked before the pandemic, but increased to 6 people who were unemployed (7.7\%). Meanwhile, there was not much change in mothers occupation before and during pandemic. Most of mothers worked as housewives, private employees or government employees. Majority of mothers had normal nutritional status, hovewer there were still mothers with underweight, overweight or even obesity.

Children data were collected from the mothers or care givers information. The median age of children was 19.00 ( $\min 0$; $\max 59$ ) months old. Children age category was devided into three groups. There were $12(15.4 \%)$ children were less than six 
months old, 38 (48.7\%) children were 6-23 months old, whereas $28(35.9 \%)$ children were 24-59 months old. Unexpectedly, gender distribution among children were evenly distributed as many as $39(50 \%)$ children were male and female with the exact same number. Children got consistent frequency of breastfeeding between before and during the covid-19 pandemic.

More than half of children $43(55.1 \%)$ still got breast milk from their mother among 78 subjects. Almost all of children 39 (90.7\%) did not experience a change in the frequency of breastfeeding, only a small proportion decreased $(7 \%)$ or even increased $(2.3 \%)$ from before the pandemic occured until it took place. The average frequency of breastfeeding was 7-8 times a day before and during pandemic.

Table 1. Subject chracteristics

\begin{tabular}{|c|c|c|c|}
\hline Variable & Category & Frequency & Percent $(\%)$ \\
\hline \multirow[t]{4}{*}{ Residence } & Java & 66 & 84.6 \\
\hline & Sumatra & 7 & 9.0 \\
\hline & Kalimantan & 2 & 2.6 \\
\hline & Sulawesi & 3 & 3.8 \\
\hline Family income & Decline & 44 & 56.4 \\
\hline \multicolumn{4}{|l|}{ Pandemic } \\
\hline \multirow[t]{5}{*}{ Father Education } & Primary school & 5 & 6.4 \\
\hline & Junior high school & 1 & 1.3 \\
\hline & Senior high school & 20 & 25.6 \\
\hline & Diploma & 4 & 5.1 \\
\hline & Undergraduate or higher & 48 & 61.5 \\
\hline \multirow{5}{*}{$\begin{array}{l}\text { Father Occupation } \\
\text { before pandemic }\end{array}$} & Farmer & 2 & 2.6 \\
\hline & Trader & 7 & 9.0 \\
\hline & Government employee & 9 & 11.5 \\
\hline & Private employee & 47 & 60.3 \\
\hline & Others & 13 & 16.7 \\
\hline Father Occupation & Farmer & 3 & 3.8 \\
\hline \multirow[t]{5}{*}{ During pandemic } & Trader & 8 & 10.3 \\
\hline & Government employee & 9 & 11.5 \\
\hline & Private employee & 41 & 52.6 \\
\hline & Unemployed & 6 & 7.7 \\
\hline & Others & 11 & 14.1 \\
\hline \multirow[t]{5}{*}{ Mother Education } & Elementary school & 1 & 1.3 \\
\hline & Junior high school & 2 & 2.6 \\
\hline & Senior high school & 11 & 14.1 \\
\hline & Diploma & 10 & 12.8 \\
\hline & Undergraduate or higher & 54 & 69.2 \\
\hline & Farmer & 1 & 1.3 \\
\hline \multirow{5}{*}{ before pandemic } & Trader & 5 & 6.4 \\
\hline & Government employee & 12 & 15.4 \\
\hline & Private employee & 28 & 35.9 \\
\hline & Housewife & 29 & 37.2 \\
\hline & Others & 3 & 3.8 \\
\hline Mother Occupation & Farmer & 1 & 1.3 \\
\hline during pandemic & Trader & 6 & 7.7 \\
\hline
\end{tabular}




\begin{tabular}{|c|c|c|c|}
\hline \multirow{6}{*}{$\begin{array}{l}\text { Nutritional status of } \\
\text { mother during }\end{array}$} & Government employee & 12 & 15.4 \\
\hline & Private employee & 28 & 35.9 \\
\hline & Housewife & 29 & 37.2 \\
\hline & Others & 2 & 2.6 \\
\hline & Underweight & 10 & 13.0 \\
\hline & Normal & 43 & 55.8 \\
\hline \multirow{5}{*}{$\begin{array}{l}\text { Gender of under- } \\
\text { five children } \\
\text { Age of children }\end{array}$} & Overweight & 12 & 15.6 \\
\hline & Obese & 12 & 15.6 \\
\hline & Male & 39 & 50.0 \\
\hline & Female & 39 & 50.0 \\
\hline & less than 6 months old & 12 & 15.4 \\
\hline \multirow{5}{*}{$\begin{array}{l}\text { Breastfeeding } \\
\text { Frequecy }\end{array}$} & $6-23$ months old & 38 & 48.7 \\
\hline & $24-59$ months old & 28 & 35.9 \\
\hline & Decline & 3 & 7.0 \\
\hline & Consistent & 39 & 90.7 \\
\hline & Increase & 1 & 2.3 \\
\hline
\end{tabular}

\subsection{Bivariate Analysis}

Comparison of exclusive breastfeeding before and during Covid-19 on infants $\leq 6$ months old was described in Table 2 .

Table 2. Comparison of exclusive breastfeeding before and during pandemic on infants $\leq 6$ months old

\begin{tabular}{|c|c|c|c|c|c|}
\hline & & \multicolumn{2}{|c|}{ During Pandemic } & \multirow[b]{2}{*}{ Total } & \multirow[b]{2}{*}{$\mathrm{p}$-value } \\
\hline & & $\begin{array}{l}\text { Non Exclusive } \\
\text { Breastfeeding }\end{array}$ & $\begin{array}{c}\text { Exclusive Breast- } \\
\text { feeding }\end{array}$ & & \\
\hline Before & Exclusive & $4(33.3)$ & $0(0.0)$ & $4(33.3)$ & $0.500 *$ \\
\hline \multirow[t]{2}{*}{ Pandemic } & Breastfeeding & & & & \\
\hline & $\begin{array}{l}\text { Exclusive Breast- } \\
\text { feeding }\end{array}$ & $2(16.7)$ & $6(50.0)$ & $8(66.7)$ & \\
\hline Total & & $6(50.0)$ & $6(50.0)$ & $12(100.0)$ & \\
\hline
\end{tabular}

Proportion of exclusive breastfeeding before pandemic was $66.7 \%$ whereas $50.0 \%$ during pandemic. It was happened because because the possibility of the infant entered the weaning period and exceeded the age of 6 months so that there was a change in the status of exclusive breastfeeding to be non exclusive breastfeeding. However, there was no difference in exclusive breastfeeding practice before and during pandemic according to statistics data analysis $(\mathrm{p}>0.05)$. Recommendation to keep exclusive breastfeeding for infants's first 6 months of life was explained by The American Academy of Pediatrics. Researchs stated that exclusive breastfeeding through 6 months had greater protection against gastrointestinal infection and also respiratory tract infection [7].

Comparison of breastfeeding difficulties before and during pandemic on children less than two years old was described in Table 3. 
Table 3. Comparison of breastfeeding before and during pandemic on children less than two years old

\begin{tabular}{clcccc}
\hline & & \multicolumn{2}{c}{ During Pandemic } & & \\
\cline { 3 - 5 } & & $\begin{array}{c}\text { Did not } \\
\text { experience } \\
\text { difficulties }\end{array}$ & $\begin{array}{l}\text { Experience } \\
\text { difficulties }\end{array}$ & Total & p-value \\
\hline Before Pandemic & $\begin{array}{l}\text { Did not experience } \\
\text { difficulties } \\
\text { Experience difficulties }\end{array}$ & $38(80.9)$ & $2(4.3)$ & $40(85.1)$ & $0.500^{*}$ \\
\hline Total & & $38(0.0)$ & $7(14.9)$ & $7(14.9)$ & $47(100.0)$ \\
\hline${ }^{*}$ Mc Nemar & & $9(19.1)$ & & \\
\hline
\end{tabular}

test

Majority of mothers did not experienced difficulties in breastfeed their children $(80.9 \%)$ before and during pandemic $(85.1 \%)$. It might related to the occupational status of mothers, who were mostly housewives and had not changed from before the pandemic and when the pandemic occurred. This finding was inline with the research stated that government employee mothers, the odds of breastfeeding were reduced by half compared to housewives (AOR 0.49, 95\% CI 0.26, 0.94)[8]. It can be understood that housewives had a lot of time and focus given to the children, so that the opportunity for children to be breastfed was greater than mothers who were busy working. Research in developing country showed that mothers had high levels of knowledge about exclusive breastfeeding, but low adherence. Mothers faced barriers to exclusive breastfeeding due to the need to return to work outside the home [9]. In line with research in Canada, family also had an important role for breastfeeding practice. Fathers influence mothers' breastfeeding decisions and experiences. The main fathering role was that of supporting breastfeeding by using their knowledge to encourage and assist mothers in breastfeeding, by valuing the breastfeeding mothers, and by sharing housework and child care [10].

Behaviour during breastfeeding were described in Table 4 and Table 5.

Table 4. Behaviour of mothers to breastfeed with both breasts

\begin{tabular}{clcccc}
\hline & \multicolumn{4}{c}{ During Pandemic } & \\
\cline { 3 - 5 } & & No & Yes & Total & p-value \\
\hline Before & No & $4(9.1)$ & $0(0.0)$ & $4(9.1)$ & $1.000^{*}$ \\
Pandemic & Yes & $0(0.0)$ & $40(90.9)$ & $40(90.9)$ & \\
\hline Total & & $4(9.1)$ & $40(90.9)$ & $44(100.0)$ \\
\hline${ }^{*}$ Mc & & & & \\
Nemar test & & & &
\end{tabular}


Proportion of mothers who breastfeed with both breasts was $90.9 \%$ before pandemic and also during pandemic. Almost all of mothers keep practising breastfeed, it indicated that good behavior will be difficult to disappear even in difficult circumstances such as the Covid-19 pandemic. Standard measurement of the breastfeeding sufficiency was complicated by factors related to definitions, timing, duration of recall, or methods of analysis [11]. However, breastfeeding practice using both breasts showed mothers effort to give her breast milk as much as possible to their children. It was necessary to nurse from each breast at every feeding so both get adequate stimulation and drainage. Therefore, Furthermore, children take more milk when they nurse on both sides. But, how to know when to switch, the best way to know is when the rhythmic sucking and swallowing slows down, or the baby releases the breast. That indicates that the rate of milk flow is diminishing and it is time to move to the other side. Remove baby by inserting a finger in his mouth to release the suction, burp him, then offer the other breast and try alternating the first breast at each feeding [12].

Table 5. Behaviour of mothers to breastfeed until felt empty breasts

\begin{tabular}{cccccc}
\hline \multicolumn{7}{c}{ During Pandemic } \\
\hline Before & No & No & Yes & Total & p-value \\
Pandemic & Yes & $10(22.7)$ & $0(0.0)$ & $10(22.7)$ & $1.000^{*}$ \\
\hline Total & $0(0.0)$ & $34(77.3)$ & $34(77.3)$ & \\
\hline${ }^{*} M c$ & $10(22.7)$ & $34(77.3)$ & $44(100.0)$ & \\
\hline Nemar test & & & & &
\end{tabular}

Proportion of mothers who breastfeed until felt empty breasts was $77.3 \%$ before pandemic and also during pandemic, meanwhile behaviour to stop breastfeed before felt empty breast was still prevalent $(22.7 \%)$. Perception of the mothers about empty breast was important. Mothers who felt that their breast milk was sufficient after several breastfeeding practise, meanwhile in fact that breasts were not empty enough, it possible for the children would lack a lot of nutrients than they should.

Food availability in the family for a day was described in Table 6.

Table 6. Food availability in the family for a day

\begin{tabular}{clcccc}
\hline & & \multicolumn{2}{c}{ During Pandemic } & p- \\
\cline { 3 - 6 } & & No food available & $\begin{array}{c}\text { Food availa- } \\
\text { ble }\end{array}$ & Total & $\begin{array}{c}\text { p- } \\
\text { value }\end{array}$ \\
\hline Before & No food available & $0(0.0)$ & $0(0.0)$ & $0(0.0)$ & $0.063^{*}$ \\
Pandemic & Food available & $5(6.41)$ & $73(93.59)$ & $78(100.0)$ & \\
\hline Total & & $5(6.41)$ & $73(93.59)$ & $78(100.0)$ & \\
\hline
\end{tabular}

*Mc Nemar test 
Food were available among children, it might because of the family had sufficient income. Generally, fathers were well educated, therefore the private sectors where they work might provide a good job positions to get an adequate income for family needs. In accordance with researchs stated that high levels of educational attainment were also associated with higher income [13]. Reviews argued that nutrition was an integral component of food security, and should be embedded within all four of its dimensions - availability, access, utilization, and stability. Obstacles in food availability in the Middle East and North Africa (MENA) region, as exacerbated by the triple burden of malnutrition, where undernutrition, micronutrient deficiencies, and overweight/obesity coexist [14]. A result from another research explained that that sosioeconomic status (SES) at both individual (education, income) and neighborhood level was linked to home food availability, suggesting a need to improve the home food environment for socioeconomically disadvantaged individuals and neighborhoods [15].

\section{Conclusion}

Finally, it can be stated several conclusions that can be obtained from this study. Feeding pattern were not changed since before and during Covid-19 pandemic spread out. They were exclusive breast feeding practice, difficulties in breastfeeding, behaviour of using both breasts while giving breast milk to the children, behaviour of mothers to breastfeed until felt empty breasts and food availability among family.

\section{References}

[1]. C. Sohrabi et al., "World Health Organization declares global emergency: A review of the 2019 novel coronavirus (COVID-19),” Int. J. Surg., vol. 76, no. February, pp. 71-76, 2020.

[2]. Q. Li et al., "Early transmission dynamics in Wuhan, China, of novel coronavirusinfected pneumonia," N. Engl. J. Med., vol. 382, no. 13, pp. 1199-1207, 2020.

[3]. F. Song et al., "Emerging 2019 novel coronavirus (2019-NCoV) pneumonia," Radiology, vol. 295, no. 1, pp. 210-217, 2020

[4]. M. Wei, J. Yuan, Y. Liu, T. Fu, X. Yu, and Z.-J. Zhang, "Novel Coronavirus Infection in Hospitalized Infants Under 1 Year ofAge in China," Jama-Journal Am. Med. Assoc., pp. E1-E2, 2020.

[5]. P. Zimmermann and N. Curtis, "Coronavirus infections in children including COVID-19: An overview of the epidemiology, clinical features, diagnosis, treatment and prevention options in children," Pediatr. Infect. Dis. J., vol. 39, no. 5, pp. 355-368, 2020.

[6]. P. Dannenberg, M. Fuchs, T. Riedler, and C. Wiedemann, "Digital Transition by COVID19 Pandemic? The German Food Online Retail," Tijdschr. voor Econ. en Soc. Geogr., vol. 111, no. 3, pp. 543-560, 2020.

[7]. C. J. Chantry, C. R. Howard, and P. Auinger, "Full breastfeeding duration and associated decrease in respiratory tract infection in US children," Pediatrics, vol. 117, no. 2, pp. 425-432, 2006. 
[8]. M. T. Hunegnaw, L. D. Gezie, and A. S. Teferra, "Exclusive breastfeeding and associated factors among mothers in Gozamin district, northwest Ethiopia: A community based cross-sectional study," Int. Breastfeed. J., vol. 12, no. 1, pp. 1-8, 2017.

[9]. M. M. Thet, E. E. Khaing, N. Diamond-Smith, M. Sudhinaraset, S. Oo, and T. Aung, "Barriers to exclusive breastfeeding in the Ayeyarwaddy Region in Myanmar: Qualitative findings from mothers, grandmothers, and husbands," Appetite, vol. 96, pp. 62-69, 2016.

[10]. L. A. Rempel and J. K. Rempel, "The breastfeeding team: The role of involved fathers in the breastfeeding family,” J. Hum. Lact., vol. 27, no. 2, pp. 115-121, 2011.

[11]. T. Greiner, "Exclusive breastfeeding: measurement and indicators," Int. Breastfeed. J., vol. 9, no. 1, pp. 1-6, 2014.

[12]. A. Nadeem, J. Nadeem, M. H. Sarwar, and M. Sarwar, "Making the Decision to Breastfeed the Baby and Its Advantages for the Women' s Health," Am. J. Food Sci. Heal., vol. 3, no. 5, pp. 88-94, 2017.

[13]. A. Rodríguez-Pose and V. Tselios, "Education and income inequality in the regions of the European Union,” J. Reg. Sci., vol. 49, no. 3, pp. 411-437, 2009.

[14]. N. Hwalla, S. El Labban, and R. A. Bahn, "Nutrition security is an integral component of food security," Front. Life Sci., vol. 9, no. 3, pp. 167-172, 2016.

[15]. W. Chai, J. X. Fan, and M. Wen, "Association of Individual and Neighborhood Factors with Home Food Availability: Evidence from the National Health and Nutrition Examination Survey,” J. Acad. Nutr. Diet., vol. 118, no. 5, pp. 815-823, 2018. 